\title{
Approach in Nitrogen Fertilizer Technology for Enhanced Nitrogen Use Efficiency: Review
}

\author{
Solomon Teshome \\ Oromia Agricultural Research Institute, Bore Agricultural Research Center, P.O.Box 21, Ethiopia
}

\begin{abstract}
Nitrogen $(\mathrm{N})$ fertilizer has made a substantial contribution to the tripling of global food production over the past 50 years. During this period the main goal of applying fertilizer was to provide nutrient to plants to increase or sustain optimal crop yield. However, any fertilizer, whether in the natural, inorganic, or organic form, can harm the environment if misused. Nitrogen, the most widely applied plant nutrient, has until recently often been singled out for its adverse effects on the environment, as well as on human and animal health. The large increase in $\mathrm{N}$ fertilizer use resulted in steep decrease in $\mathrm{N}$ use efficiency. The low use efficiency of $\mathrm{N}$ fertilizer in general shows unsustainable $\mathrm{N}$ fertilizer use which resulted negative effect on the environment and economic benefit from farming. To ensure that proper use of nitrogen fertilizer that maintain beneficial to both crop production and the environment, researchers and fertilizer producers have tried to find ways to achieve the newly defined Enhanced fertilizer efficiency. Therefore, the objective of this seminar is to review achievements so far made in the area of Nitrogen fertilizers technology. The fate of applied fertilizer nitrogen in agricultural ecosystems is dependent on the immobilization and mineralization of nitrogen by various biotic and abiotic factors. When $\mathrm{N}$ fertilizer is applied to crops under very distinct agricultural systems, plants rarely recover more than $50 \%$ of the fertilizer-N. The remainder is lost from the soil-plant system by mechanisms like volatilization, denitrification, leaching out of the root zone and being carried out by soil or water erosion. NUE in plants is a function of capacity of soil to supply levels of nutrients and ability of plant to acquire, transport in roots and shoots and remobilize to other parts of the plant. Different methods have been proposed in recent years to reduce loss of $\mathrm{N}$ from agriculture field. One of the methods is enhanced efficiency of fertilizer. Enhanced efficiency of fertilizer includes additives, physical barrier and chemical formulation. Therefore considering both the economic and environmental challenge represented by reducing both the cost and application of $\mathrm{N}$ fertilizers is critical.
\end{abstract}

Keywords: Efficiency, Enhanced, Fertilizers, Nitrogen, Nutrient

DOI: $10.7176 / \mathrm{JBAH} / 9-8-04$

Publication date: April $30^{\text {th }} 2019$

\section{Introduction}

Nitrogen $(\mathrm{N})$ fertilizer has made a substantial contribution to the tripling of global food production over the past 50 years. World grain production was 631 million tons in 1950 (247 kg person $\left.{ }^{-1}\right)$ and 1840 million tons in 2000 (303 kg person ${ }^{-1}$ ); per capita grain production peaked in 1984 at $342 \mathrm{~kg}$ person $^{-1}$ (Mosier et al., 2004). During this period the main goal of applying fertilizer was to provide nutrient to plants to increase or sustain optimal crop yield. Thus, improving fertilizer use efficiency in terms of nutrient uptake and crop yield is important to fertilizer producers and users. However, any fertilizer, whether in the natural, inorganic, or organic form, can harm the environment if misused (Chien et al., 2009). Increased use of chemical fertilizers (N) in agricultural production continues to raise concerns because of the risk of surplus $\mathrm{N}$ leaving the plant soil system and thereby causing environmental contamination (Bagheri et al., 2011).

The loss of $\mathrm{N}$ lowers the effectiveness of $\mathrm{N}$ fertilization and at the same time can have serious environmental implications when excess $\mathrm{N}$ enters the natural environment. Nitrogen, the most widely applied plant nutrient, has until recently often been singled out for its adverse effects on the environment, as well as on human and animal health (Jat et al., 2012). Globally the consumption of $\mathrm{N}$ fertilizer is increased dramatically in recent years. In many developed countries, cereal yield have continued to increase in the past 20 years with substantial declines in $\mathrm{N}$ use in some areas. While, in developing world early in 1960's and increased exponentially during the course of green revolution. The large increase in $\mathrm{N}$ fertilizer use resulted in steep decrease in $\mathrm{N}$ use efficiency (Dobermann, 2007). The low use efficiency of $\mathrm{N}$ fertilizer in general shows unsustainable $\mathrm{N}$ fertilizer use which resulted negative effect on the environment and economic benefit from farming. $\mathrm{N}$ leaching from sandy soil are especially troublesome in the arid regions (Bahr et al., 2006).

To ensure that proper use of nitrogen fertilizer that maintain beneficial to both crop production and the environment, researchers and fertilizer producers have tried to find ways to achieve the newly defined Enhanced fertilizer efficiency. Therefore, the objective of this seminar is to review achievements so far made in the area of Nitrogen fertilizers technology.

2. Understanding NITROGEN fate in agro-ecosystem

The fate of applied fertilizer nitrogen in agricultural ecosystems is dependent on the immobilization and 
mineralization of nitrogen by various biotic and abiotic factors called nitrogen sinks (Manske, n.d.). $\mathrm{N}$ dynamics in soils of tropical humid regions is characterized by its great mobility and high organic matter mineralization rates due to the prevalence of higher temperatures (Meirelles et al., 1980). When $\mathrm{N}$-fertilizer is applied to crops under very distinct agricultural systems, plants rarely recover more than $50 \%$ of the fertilizer-N. Some of it remains in the soil or is immobilized in the litter. The remainder is lost from the soil-plant system by mechanisms like volatilization, denitrification, leaching out of the root zone and being carried out by soil or water erosion (Trivelin et al., 1995; Bustamante et al., 1997; Gava et al., 2001). In general, there are four ways of loss of $\mathrm{N}$ fertilizer in agro-ecosystem.

\subsection{Ammonia volatilization}

$\mathrm{N}$ fertilizers also account for $33 \%$ of the total annual creation of reactive $\mathrm{N}$ or $63 \%$ of all anthropogenic sources of reactive nitrogen. Reactive nitrogen is defined as all biologically, photochemically, and/or radiatively active forms of $\mathrm{N}$ a diverse pool of nitrogenous compounds that includes organic compounds (e.g. urea, amines, proteins, amides), mineral $\mathrm{N}$ forms, such as $\mathrm{NO}_{3}$ and $\mathrm{NH}_{4}{ }^{+}$as well as gases that are chemically active in the troposphere $\left(\mathrm{NO}_{\mathrm{x}}, \mathrm{NH}_{3}, \mathrm{NO}\right)$ and contribute to air pollution and the greenhouse effect. Asia alone accounts for more than $50 \%$ of the global $\mathrm{N}$ fertilizer consumption as well as $37 \%$ for the global $\mathrm{Nr}$ creation (Dobermann, 2007).

Applying $\mathrm{N}$ as a commercial fertilizer/animal manure without incorporation can result in large $\mathrm{N}$ losses in the form of ammonia gas $\left(\mathrm{NH}_{3}\right)$. Volatilization losses are dependent upon many factors. For urea and manure applied but not incorporated, losses can be very significant. Surface runoff is only a concern when fertilizer is applied on the ground and a rain moves the $\mathrm{N}$ before it is in the soil. Rain on a field that received $\mathrm{N}$ while frozen could lead to significant $\mathrm{N}$ losses (Onfarm Network, 2008). Estimated that only about half of all anthropogenic $\mathrm{N}$ inputs to cropland are taken up by harvested crops and their residues, with the remainder contributing significantly to $\mathrm{Nr}$ enrichment of the atmosphere, ground and surface waters.

\subsection{Denitrification}

Simply stated, when sufficient oxygen is not available in the soil, some microorganisms use oxygen from the nitrate ion. When oxygen is removed from nitrate, it leaves $\mathrm{N}$ gas, which can then be lost to the atmosphere. This is denitrification. Soil conditions that lead to denitrification typically occur when moisture is high or there is standing water, and conditions are warm enough to encourage microbial activity. Loss due to denitrification can be significant, especially in a wet year. When the soil microorganisms need oxygen, they will take it from the air or from nitrate if the water in the soil prevents them (Onfarm Network, 2008).

\subsection{Leaching}

Leaching is responsible for most $\mathrm{N}$ losses from agricultural fields. This occurs when there is enough rain to cause water to move down through the soil, percolating into the water table, seeping into streams, or into tile lines, and away from the field (Onfarm Network, 2008). Nitrate leaching potential depends on soil properties, crops and crop rotation, irrigation methods, management practices and climatic parameters. This necessitates the development of appropriate water and fertilizer application strategies so as to maximize their application efficiency and minimize fertilizer losses through leaching (Ajdary et al., 2007).

\subsection{Soil erosion}

In general, nitrogen losses due to erosion are negligible. It should be noted that erosion loss is different from surface runoff. Surface runoff is only a concern when fertilizer is applied on the ground and a rain moves the $\mathrm{N}$ before it is in the soil. Rain on a field that received $\mathrm{N}$ while frozen could lead to significant $\mathrm{N}$ losses.

\section{Progress in $\mathbf{N}$ fertilizer technology}

Synthetic ammonia $\left(\mathrm{NH}_{3}\right)$, the principal source of all nitrogen fertilizers, provided only half of the world's inorganic $\mathrm{N}$ in 1931; by 1950 that share was almost 80 percent and by 1962, more than 90 percent. During the late 1990s, Haber-Bosch synthesis supplied more than 99 percent of fixed inorganic nitrogen, with the remainder primarily from Chilean nitrate and by-product ammonia from coke ovens. Nitrogen fertilizers can be classified into four groups depending on their chemical form: ammonium fertilizers, nitrate fertilizers, combined ammonium and nitrate fertilizers, and amide fertilizers

\section{Enhanced Efficiency of $\mathbf{N}$ fertilizer}

NUE in plants is a function of capacity of soil to supply levels of nutrients and ability of plant to acquire, transport in roots and shoots and remobilize to other parts of the plant. Plants interaction with environmental factors such as solar radiation, rainfall, temperature and their response to diseases, insect and allelopathy and root microbes have a great influence on NUE in plants (Baligar et al., 2001). There are three primary mechanism 
of enhancing nutrient use efficiency other than management practices of timing and placement method mentioned previously. These are additives, physical barrier and chemical formulation that enhance the efficiency of fertilizer.

\subsection{Slow release through coating}

Controlled release fertilizers use coatings which delay or extend the nutrient availability. Polymer-coated controlled-released fertilizers look promising for widespread use in agriculture because they can be designed to release nutrients in more in controlled manner. The polymers are generally durable and exhibit consistent release nutrients rates that are predictable when average temperature and moisture conditions can be estimated (Blaylock et al., 2005). They are made at the manufacturing plant. The most common coated slow/controlled-release fertilizers are sulfur- and polymer-coated Products.

Table 1. Fertilizer $\mathrm{N}$-use efficiencies of wheat as influenced by sources and rates of $\mathrm{N}$ at Ludhiana and Gurdaspur, India.

\begin{tabular}{|c|c|c|c|c|}
\hline \multirow[t]{2}{*}{ Treatment } & \multicolumn{2}{|l|}{ Lundhiana } & \multicolumn{2}{|l|}{ Gurdaspur } \\
\hline & $\begin{array}{l}\text { Agr. efficiency } \\
\left(\mathrm{kg}_{\text {grain }} \mathrm{kgN}^{-1}\right)\end{array}$ & Recovery efficiency (\%) & $\begin{array}{l}\text { Agro. efficiency (kg } \\
\left.\text { grain } \mathrm{kgN}^{-1}\right)\end{array}$ & $\begin{array}{l}\text { Recovery } \\
\text { efficiency (\%) }\end{array}$ \\
\hline \multicolumn{5}{|l|}{ Control } \\
\hline Urea $\left(48 \mathrm{kgNha}^{-1}\right)$ & 20.6 & 47.9 & 30.0 & 72.9 \\
\hline Urea $\left(96 \mathrm{Nha}^{-1}\right)$ & 22.0 & 52.0 & 22.4 & 76.0 \\
\hline Urea $\left(120 \mathrm{Nha}^{-1}\right)$ & 19.2 & 53.3 & 21.2 & 80.8 \\
\hline $\mathrm{NCU}\left(48 \mathrm{kgNha}^{-1}\right)$ & 25.8 & 70.8 & 32.5 & 91.7 \\
\hline NCU $\left(96 \mathrm{kgNha}^{-1}\right)$ & 24.2 & 66.7 & 24.5 & 87.5 \\
\hline NCU $\left(120 \mathrm{kgNha}^{-1}\right)$ & 20.0 & 60.0 & 21.8 & 83.3 \\
\hline Urea $\left(120 \mathrm{kgN} \mathrm{ha}^{-1}\right)$ & 23.9 & 66.7 & 19.3 & 65.0 \\
\hline NCU $\left(120 \mathrm{kgha}^{-1}\right)$ & 24.2 & 75.8 & 19.8 & 66.7 \\
\hline Urea $\left(96 \mathrm{kgNha}^{-1}\right)$ & 26.7 & 77.1 & 21.6 & 70.8 \\
\hline $\operatorname{NCU}\left(96 \mathrm{kgN} \mathrm{ha}^{-1}\right)$ & 29.4 & 79.2 & 22.0 & 67.7 \\
\hline
\end{tabular}

Source Jat et al. (2010).

Sulfur coatings have been used to delay urea release from individual fertilizer granules at different times to achieve an extended period of N supply. Nitrogen release from sulfur-coated urea (SCU) has been somewhat unpredictable, and use of SCUs has become less common. More recently, a variety of polymers are used to form semi-permeable coatings on soluble $\mathrm{N}$ sources, usually urea. Release is regulated by polymer chemistry, coating thickness, soil moisture, and soil temperature. Because of high cost, CRN use in agriculture is limited, accounting for less than $1 \%$ of worldwide fertilizer consumption. Recent advancements have decreased production costs to an economical level for commodity grain crops (Blaylock et al., 2005; Olson-Rutz, 2011). On the other hand, Eyvanzy et al. (2010) found that application of pellet fertilizers improve the quantity and quality of wheat yield and its components as compared to uncoated urea. In addition to this pelleting urea with cow dung contribute to the improvement of soil organic matter that is key for sustainable agricultural production. Killorn et al. (2011) found polymer-coated urea material (ESN) fertilizer has a yield advantage over a urea fertilizer applied.

\subsection{Slow release through chemical formulation}

$\mathrm{N}$ fertilizers predominantly contain $\mathrm{N}$ in a form of ammonia, nitrate, or urea (Roy and Hammond, 2004). Specialty products that are basically modifications of the previously mentioned products (e.g., granular, liquid, or suspended forms, controlled release compounds, or fertilizers containing urease and nitrification inhibitors or other essential nutrients) have been and continue to be developed. New technologies employing controlled release fertilizers and nitrification inhibitors have the potential to reduce $\mathrm{N}$ loss markedly and to improve NUE (Giller et al., 2004).

Controlled release $\mathrm{N}$ products release their nutrients at a slower rate than conventional fertilizers. Slow release fertilizers are excellent alternative to soluble fertilizers. Because nutrients are released at a slower rate throughout the season, plants are able to take up most of the nutrients without waste by leaching. A slow release fertilizer is more convenient since less frequent applications required (Bohr et al., 2006). Slow release fertilizers use additives such as urea-aldehyde products that slowly decompose by chemical and/or biological processes in the soil delaying $\mathrm{N}$ release. Solubility and $\mathrm{N}$ release can be varied by altering the chemical composition of the aldehyde additive (Blaylock and Tindall, 2006). Bohr et al (2006) stated that maize yield and yield components were increased significantly with application of slow releasing $\mathrm{N}$ fertilizer (Enciabien $10 \%$ ).

The release of $\mathrm{N}$ from PCUs is determined by soil moisture and temperature. Moisture generally does not limit nutrient release in the range of soil moisture adequate for crop growth, but is necessary to allow diffusion of urea from the PCU prill. Moisture limitations on nutrient release rate are most commonly a factor with surface 
application in areas of sparse rainfall (10). In the presence of moisture, temperature is the major controlling mechanism of release rate. In one lab study on a silt loam soil, only 30 percent of $\mathrm{N}$ was released

\subsection{Inhibition of Processes}

Urea based $\mathrm{N}$ products are $\mathrm{N}$ fertilizers used worldwide for crop production today, especially urea's due to its high $\mathrm{N}$ content. However, $\mathrm{NH}_{3}$ volatilization can be a significant $\mathrm{N}$ loss mechanism for urea when applied to the surface, especially for neutral, alkaline and flooded soils, at the early stage of plant growth (Chein et al., 2009). Various studies has been conducted to minimize volatilization of $\mathrm{N}$ using fertilizer additives. Fertilizer additives are products which added to fertilizer to help protect against loss pathways. The most widely used additives are nitrification inhibitions (Killorn et al., 2011). Nitrification inhibitors are compounds that delay bacterial oxidation of the ammonium ion $\left(\mathrm{NH}_{4}^{+}\right)$by depressing the activities of Nitrosomonas bacteria in the soil over a certain period. They are responsible for the transformation of ammonium into nitrite $\left(\mathrm{NO}_{2}^{-}\right)$, which is further oxidized to nitrate $\left(\mathrm{NO}_{3}^{-}\right)$by Nitrobacter and Nitrosolobus bacteria. The objective of using nitrification inhibitors is, therefore to control the leaching of nitrate by keeping $\mathrm{N}$ in the ammonium form for longer, to prevent denitrification of nitrate-N and increase the efficiency of $\mathrm{N}$ applied (Jat et al., 2012).

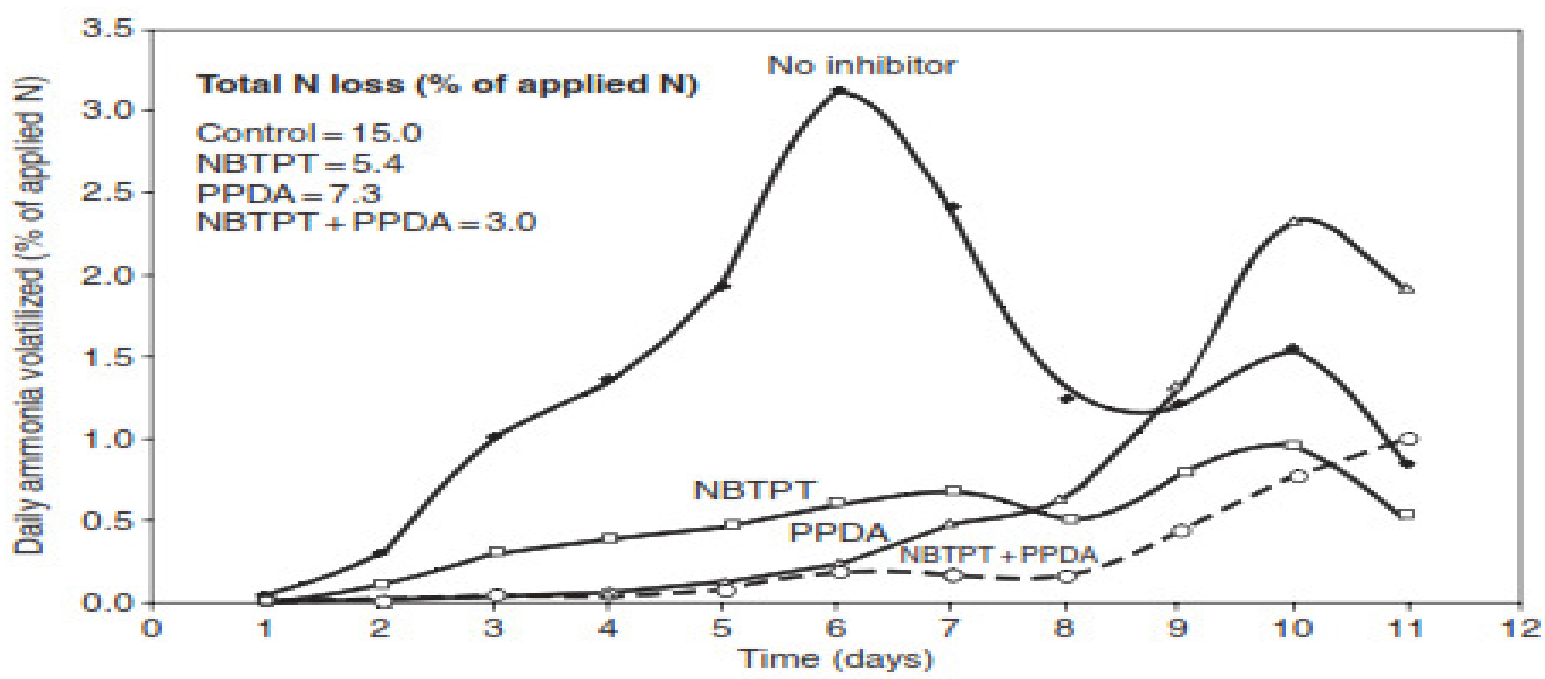

Fig 1. Ammonium volatalization as affected by urease inhibitor treatment in flooded ricem soil Source:

The most widely use nitrification inhibitor is nitrapyrin (N-serve $\left.{ }^{\circledR}\right)$. Dicynandiamide (DCD) is another effective nitrification inhibitor. These products temporarily suppress the population of nitrosomonas bacteria in soil which convert ammonia $\left(\mathrm{NH}_{4}^{+}\right)$to nitrate $\left(\mathrm{NO}_{3}{ }^{-}\right)$(Chein et al., 2009). Several studies with nitrapyrin, DCD and 3.4-dimethylpyrazolephosphate (DMPP) nitrification inhibitors on winter whaet, corn, rice, grain sorghum, sugar beet and cotton have demonstrated that nitrification inhibitors suppress nitrification, improve $\mathrm{N}$ recovery and increase the economic yields significantly (Jat et al., 2012).

\section{Discussion}

Nitrogen is one of the most important nutrient and required in large quantity for growth and development of plants. Largely $\mathrm{N}$ is supplied through fertilizers and found to be mobile nutrient in soil plant system. As a result in NUE of crop production is very low that only $51 \%$ of the applied was recovered by the above ground parts of biomass. Even it is very low under certain management.

Nitrogen derived from fertilizers and not taken up by plants may be immobilized in soil organic matter or may be lost to the environment. In this case, it has the potential to become a pollutant of ground or surface waters or to contribute to the greenhouse effect. Loss of $\mathrm{N}$ to the environment usually takes place when high concentrations of soluble $\mathrm{N}$ forms are present in the soil solution in excess compared to the amount that plants can take up or when in periods or positions in the soil profile where there are no plants or roots to make use of the available N. These problems can be largely overcome with good management practices, which include selecting a rate of application compatible with plant needs, placing the fertilizer where plants can easily reach the nutrients, and choosing the right application time. In many cases for $\mathrm{N}$, this implies splitting the application in two or more time intervals. Management practices will not be discussed in this text, except urea supergranules (USG) for deep placement in lowland rice soils.

Recently, the Association of American Plant Food Control Officials has adopted the term enhanced efficiency fertilizers (EEF) to characterize products that can minimize the potential of nutrient loss to the environment, as compared to reference soluble sources. EEF includes slow-release or controlled-release 
fertilizers, which comprise coated, water-insoluble or slowly water-soluble products, and stabilized fertilizers which are those amended with additives that reduce the transformation rate of fertilizer compounds, resulting in an extended time of availability in the soil. There are two important groups of fertilizers classified as slow or controlled-release fertilizers. One group is formed by condensation products of urea and urea aldehydes, of which the most significant types on the market are urea formaldehyde (UF), isobutylidene diurea (IBDU), and crotonylidene diurea (CDU). The second group is comprised of coated or encapsulated fertilizers, such as Scoated urea (SCU) or polymer-coated urea (PCU). Examples of the stabilized nitrogen fertilizers are those treated with inhibitors, such as nitrification or urease inhibitors, that may avoid the rapid transformation of $\mathrm{N}$ into forms that are less stable in certain environments.

\section{Conclusion}

Increased use of $\mathrm{N}$ fertilizer have been observed in recent decades. The use of these fertilizer have both economic and environmental implications. Only about 51\% of applied fertilizer is recovered from cereal field. About half is lost through volatilization contribute to global warming, leaching contribute to eutrophication and mineralized into other form. Different methods have been proposed in recent years to reduce loss of $\mathrm{N}$ from agriculture field. One of the method is enhanced efficiency of fertilizer. Enhanced efficiency of fertilizer include additives, physical barrier and chemical formulation.

The two main types of manufactured controlled-release fertilizers (CRFs) are coated fertilizers and slowly soluble urea-aldehyde reaction products. Commercial urea-aldehyde reaction products include ureaformaldehyde (UF), isobutylidenediurea (IBDU), and crotonylidene diurea (CDU). Coated fertilizers mainly consist of sulfur-coated urea (SCU), polymer- and sulfur-coated urea (P/SCU), and polymercoated (including resin-coated) fertilizers (PCFs). Today, all SCU produced in North America is P/SCU with a typical grade of 42 percent $\mathrm{N}$ and 5 percent S. In 2001 about 30,000 tons of CRFs were consumed in the United States for agricultural crops, whereas 486,000 tons were consumed in nonagricultural markets. Therefore considering both the economic and environmental challenge represented by reducing both the cost and application of $\mathrm{N}$ fertilizers is critical.

\section{Reference}

Ajdary, K., Singh, D.K., Singh, A.K. and Khanna, M., 2007. Modelling of nitrogen leaching from experimental onion field under drip fertigation. Agricultural Water Management 89: 15-28.

Bagheri, R., G. Ali-Akbari, M. Hossein-Kianmehr, Z. A. Sarvastani and M. Hamzekhanlu, 2011. The effect of pellet fertilizer application on corn yield and its components. African Journal of Agricultural Research Vol. 6(10), pp. 2364-2371. Doi: 10.5897/AJAR11.01.

Baligar, V. C., Fageria, N. K. and He Z. L., 2001. Nutrient use efficiency in plants, Communications in Soil Science and Plant Analysis, 32:7-8, 921-950. Doi: http://dx.doi.org/10.1081/CSS-100104098.

Blaylock, A.D., J. Kaufmann and R.D. Dowbenko, 2005. Nitrogen Fertilizer Technologies. Western Nutrient Management Conference, Vol. 6.

Blaylock, A. D. and T. A. Tindall. 2006. Advances in slow-release nitrogen fertilizers. In: Proceedings, Great Plains Soil Fertility Conference. March 7-8. Denver, Colorado. Pp. 37-43.

Bohr A. A., Zeidon M. S. and Hozayn M. 2006. Yield and Quality of Maize (Zea mays L.) as affected by SlowRelease Nitrogen in Newly Reclaimed Sandy soil. American-Eurasian J. Agricultural and Environmental Science, 1 (3):239-242

Bohr A. A., Zeidon M. S. and Hozayn M., 2006. Yield and Quality of Maize (Zea mays L.) as affected by SlowRelease Nitrogen in Newly Reclaimed Sandy soil. American-Eurasian J. Agricultural and Environmental Science, 1 (3):239-242.

Bustamante C, Ochoa M and Rodriguez M. I. 1997. Balance of three nitrogen $15 \mathrm{~N}$ fertilizers in a Cuban Oxisol cultivated with Coffea arabica L. Tropicultura, Brussel. 15, n.4, 169-172.

Chien S. H., Prochnow L. I. and Cantarella H. 2009. Recent Developments of Fertilizer Production and Use to Improve Nutrient Efficiency and Minimize Environmental Impacts. Advances in agronomy, Vol. 102. Pp 268-306.

Eyvazi J., Irannejad H., Kianmehr M. H., Esmaeili M., Akbari Q. A. and Onwonga R. N. 2010. The effect of Pellet fertilizer application on Wheat Yield and its Components. International Research Journal of Plant Science, Vol. 1(6) pp. 163-171.

Gava G J de C, Trivelin P C O, Oliveira M W and Penatti C. P. 2001 Growth and nitrogen accumulation of sugarcane grown on soil with harvest trash cover. Pesquisa Agropecuária Brasileira, Brasília. 36. 1347-1354.

Giller, E. K., P. Chalk, A. Dobermann, L. Hammond, P. Heffer, J. K. Ladha, P. Nyamudeza, L. Maene, H. Ssali and J. Freney, 2004. Emerging Technologies to Increase the Efficiency of Use of Fertilizer Nitrogen. In: Mosier A. R., Syers J. K. and Freney J. R. (Ed.). Agriculture and the Nitrogen Cycle Assessing the Impacts of Fertilizer Use on Food Production and the Environment. SCOPE 65. 
Jat R. A., Suhas P. Wani, Kanwar L. Sahrawat, Piara Singh , S.R. Dhaka and B.L. Dhaka, 2012. Recent approaches in nitrogen management for sustainable agricultural production and eco-safety, Archives of Agronomy and Soil Science, 58:9, 1033-1060. DOI: http://dx.doi.org/10.1080/03650340.2011.557368

Killorn R., Gonzalez M. and Rueber D. 2011. Effect of slow release N fertilizer on corn yield. Iowa State University, Northern Research and Demonstration Farm. Manske, n.d.).

Meirelles, N. M. F., Libardi P. L. and Reichardt K. 1980. Nitrogen absorption and leaching in a snap bean crop (Phaseolus vulgaris L.). Revista Brasileira de Ciência do Solo. Campinas. 4, 83-88.

Mosier, A. R., Syers J. K., and Freney J. R. 2004. Nitrogen Fertilizer: An Essential Component of Increased Food, Feed, and Fiber Production. In: Mosier A. R., Syers J. K. and Freney J. R. (Ed.). Agriculture and the Nitrogen Cycle Assessing the Impacts of Fertilizer Use on Food Production and the Environment. SCOPE 65 .

Olson-Rutz, K. 2011. Enhanced Efficiency of Fertilizers. Montana State University Extension, EB0188.

Onfarm Network, 2008).

Roy, A. H. and L. L. Hammond, 2004. Challenges and opportunities for the fertilizer industry. In: Mosier A. R., Syers J. K. and Freney J. R. (Ed.). Agriculture and the Nitrogen Cycle Assessing the Impacts of Fertilizer Use on Food Production and the Environment. SCOPE 65.

Shaviv, A., 2005. Controlled release fertilizers. In: IFA International Workshop on Enhanced Effciency Fertilizers; 2005 June 28-30; Frankfurt, Germany. http://www.fertilizer.org/ifa/ HomePage/Library/Conference-papers/Agriculture-Conferences/2005-IFA-agriculture Workshop. Accessed 13 April 2013.

Trivelin, P. C. O., Victoria R. L. and Rodrigues S. C. S. 1995. Use by sugarcane ratoon at harvest season end of aquammonia-15N and urea-15N applied to the soil as a complement to vinasse. Pesquisa Agropecuária Brasileira, Brasília. 30, 1375-1385. 